\title{
REALITAS SOSIAL DALAM NOVEL PULANG KARYA LEILA S. CHUDORI: KAJIAN STRUKTURALISME GENETIK
}

\author{
Siti Nurfitriani \\ Universitas Negeri Jakarta \\ E-mail: sitinurfitriani51@gmail.com \\ DOI: http://dx.doi.org/10.17509/bs_jpbsp.v17i1.6961
}

\begin{abstract}
Abstrak
Penelitian ini bertujuan untuk mengetahui realitas sosial dalam novel Pulang karya Leila S. Chudori yang dikaji berdasarkan pendekatan strukturalisme genetik. Relitas sosial yang dikaji dalam penelitian ini dilihat pada unsur cerpen, struktur sosial masyarakat, dan pandangan dunia pengarang (world view). Penelitian ini menggunakan pendekatan kualitatif dengan metode analisis isi yang didukung oleh kajian strukturalisme genetik. Hasil penelitian menunjukkan bahwa pada subfokus terdapat realitas sosial dalam unsur novel Pulang karya Leila S. Chudori khususnya di dalam tema cerita. Realitas sosial yang terdapat dalam tema berupa perjuangan para eksil politik untuk kembali menginjakkan kaki ke tanah air. Peristiwa yang dialami tokoh-tokoh dalam cerita sesuai dengan aspek sosial yang terjadi pada para eksil politik di Indonesia. Selain pada tema realitas sosial juga muncul pada latar, sudut pandang, serta penokohan. Pada subfokus selanjutnya realtas ditinjau dari stuktur sosial masyarakat dapat diketahui bahwa terdapat realitas sosial di dalam novel yang sesuai dengan struktur sosial masyarakat di antaranya adalah peristiwa G30SPKI, peristiwa supersmar, pembersihan etnis Tionghoa, serta tragedi Mei. Sementara pada subfokus pandangan dunia pengarang ditemukan melalui tokoh problematik di dalam cerita bahwa pengarang dalam wawancaranya menyatakan bahwa eskil politik merupakan warga negara Indonesia yang berhak mendapat kehidupan yang layak sebagaimana warga Indonesia pada umumnya. Berdasarkan penelitian yang ditemukan menunjukkan bahwa penelitian ini dan novel Pulang dapat dijadikan sebagai bahan bacaan untuk siswa dan masyarakat umum untuk memperluas wawasan mengenai sejarah.
\end{abstract}

Kata kunci: realitas sosial, sejarah, strukturalisme genetik.

\section{SOCIAL REALITY IN THE NOVEL PULANG BY LEILA S. CHUDORI: STUDY OF GENETIC STRUCTURALISM}

\begin{abstract}
This study aims to determine the social reality in the novel Pulang Leila Chudori works were assessed on the basis of genetic structuralism approach. Social reality examined in this study extend short story structure, social structure, and the author's view of the world (world view). The method used in this study is a qualitative method that is supported by the study of genetic structuralism. The results showed that there subfokus social reality in a novel structure Pulang Leila Chudori work, especially in the theme of the story. Social reality contained in the theme in the form of the struggle of the political exiles to return to set foot into the ground water. Events experienced by the characters in the story according to the social aspect that occurs in the political exiles in Indonesia. In addition to the social reality theme also appears in the background, viewpoint, and the characterizations. In the next subfokus realtas society in terms of social structure can be seen that there is a social reality in the novel in accordance with the social structure of which is G30SPKI events, events supersmar, Chinese ethnic cleansing, as well as the May Tragedy. While the authors found subfokus world view through a problematic figure in the story that the author in an interview stated that political eksil an Indonesian citizen who is entitled to a decent living as citizens of Indonesia in general. Based on these results until it can be understood thoroughly and deeply concerning novel Leila Chudori when viewed from the study of genetic structuralism. Research results obtained show that the novel Pulang to contain social reality that can be used as reading material for students and the general public to broaden insight into the history.
\end{abstract}

Keywords: social reality, history, genetic structuralism. 


\section{PENDAHULUAN}

Wellek dan Warren mendefinisikan karya sastra dengan membatasinya pada mahakarya (great books), yaitu buku-buku yang dianggap menonjol karena bentuk dan ekspresi sastranya. Dalam hal ini kriteria yang dipakai adalah segi estetis yang dikombinasikan dengan nilai ilmiah. (Wellek dan Warren, 1993, p. 12) Seperti yang diungkapkan Wellek dan Warren bahwa sastra merupakan sebuah mahakarya yang tidak hanya menonjolkan unsur estetsis, gaya bahasa, komposisi, dan kekuatan penyampaiannya tetapi juga sebuah karya yang memiliki nilai ilmiah. Nilai ilmiah di dalam karya sastra salah satunya tercermin melalui bentuk-bentuk realtas sosial budaya yang terkandung di dalam karya sastra.

Salah satu novel yang mengandung realitas sosial ialah novel Pulang karya Leila S. Chudori. Dipilihnya novel Pulang sebagai kajian dalam penelitian ini. Pertama, novel ini mengandung realitas sosial. Salah satu bentuk realitas sosial yang terjadi di dalam Pulang karya Leila S. Chudori mengenai kehidupan tapol (tahanan politik) Indonesia yang harus mengalami penderitaan sepanjang hidupnya karena dianggap mengikuti organisasi-organisasi komunis. Kedua novel ini merupakan novel yang memiliki tema sejarah yaitu sejarah Indonesia September 1965, Prancis 1968, dan Indonesia Mei 1998. Ketiga, novel Pulang dapat menggambarkan kesadaran kepada pembaca mengenai realitas sejarah yang terjadi pada masyarakat Indonesia.

Berdasarkan latar belakang tersebut, fenomena yang terjadi dalam novel Pulang memunculkan kesadaran sosial untuk melihat fakta, sejarah dan realitas sosial yang terjadi pada masyarakat Indonesia. Novel Pulang dalam hal ini merupakan refleksi pemikiran yang menyangkut masalah sosial, politik, dan budaya dari pengarang yang dikemas dengan bahasa yang menarik, artistik dan metaforis. Novel ini merupakan hasil renungan dan riset yang dihasilkan pengarang dengan proses sejarah yang terjadi pada proses novel tersebut diciptakan.

Penelitian terhadap novel Pulang karya LeIila S. Chudori dilakukan dengan pendekatan strukturalisme genetik guna menemukan realitas sosial di dalam novel tersebut. Goldmann (1975) mengungkapkan bahwa pendekatan strukturalisme genetik adalah pendekatan yang memandang sebuah karya sastra dari struktur, pandangan sosial kelompok pengarang, dan kondisi ekternal pengarang untuk menemukan world view atau pandangan dunia. (Endraswara, 2002, p. 27). Dasar pemahaman strukturalisme genetik ialah konteks karya sastra tidak dapat dilepaskan begitu saja dari kelas-kelas sosial yang ada. Karya sastra merupakan ideologi dari pengarang yang menempati kelas sosial tertentu. (Emzir, 2015, p.35)

Berdasarkan paparan di atas dapat diketahui bahwa teori strukturalisme genetik menekankan hubungan antara karya dengan lingkungan sosialnya. Dalam masyarakat sesungguhnya manusia berhadapan dengan norma dan nilai, dalam karya satra juga diceriminkan norma dan nilai yang secara sadar difokuskan dan diusahakan untuk dilaksanakan dalam masyarakat. Sastra juga melukiskan kecemasan, harapan, dan aspirasi manusia. Oleh karena itu hal tersebut sesuai dengan yang diungkapkan oleh Budi Dharma bahwa strukturalisme genetik nenekankan pada struktur mental karya sastra yaitu proses sejarah dan kebudayaan. Dengan demikian, sastra adalah refleksi pengamatan manusia terhadap proses sejarah dan kebudayaan. (Dharma, 2012, p. 14)

Dalam menganalisis novel ini, peneliti menggunakan prosedur penelitian strukturalisme genetik untuk menemukan bentuk-bentuk realitas sosial dan mencari pandangan dunia pengarang dalam novel. Pandangan dunia di dalam novel ini perlu diketahui sejauhmana gambaran yang terkandung di dalam novel dengan realitas kehidupan. Adapun prosedur yang dilakukan dalam penelitian strukturalisme genetik ialah a) meneliti unsur-unsur karya sastra, 
b) hubungan unsur-unsur karya sastra dengan totalitas karya sastra, c) meneliti unsur-unsur masyarakat yang berfungsi sebagai genesis karya sastra, d) hubungan unsur-unsur masyarakat dengan totalitas masyarakat, e) hubungan karya sastra secara keseluruhan dengan masyarakat secara keseluruhan . (Ratna, 2005, p. 127)

Novel Pulang sebagai sebuah katya sastra memiliki fungsi ganda yakni selain menghibur juga bermanfaat bagi pembacanya karena mengandung unsur realitas sosial. Maka, dengan membaca karya sastra, pembaca akan memperoleh nilai-nilai kehidupan yang agung dan pengetahuan yang mendalam mengenai realitas sosial yang terjadi pada masyarakat. Dengan demikian, karya sastra sebagai produk budaya yang mengejawantahkan pengalaman dan nilainilai kehidupan dapat dijadikan media dan sumber belajar untuk dunia pendidikan, khususnya di sekolah. Hal tersebut seperti yang diungkapkan oleh Nyoman Kutha Ratna "Secara etimologis, sastra juga berarti alat untuk mendidik. Lebih jauh dikaitkan dengan pesan dan muatannya. Hampir secara keseluruhan karya sastra merupakan sarana estetika". (Ratna, 2005, p. 428)

Melalui pembacaan terhadap karya sastra secara tidak langsung pembaca mendapatkan pesan dan nilai moral melalui muatan cerita yang ada dalam sebuah karya. Hal tersebut sesuai dengan ucapan yang diungkapkan oleh Taufik Ismail pada acara "Sastrawan Bicara Mahasiswa Membaca" di PBS UNJ Tahun 2002 yang dikutip oleh Djojosuroto (2006) mengungkapkan bahwa dengan mambaca karya sastra dapat membukakan mata pembaca untuk mengetahui realitas sosial dan budaya dalam bingkai moral dan estetika. Melalui karya sastra peserta didik dapat menikmati realitas imajinasi pengarang melalui tokoh, peristiwa, dan latar yang disajikan.

Selain itu, agar pendidik dapat memilih bahan ajar dengan tepat, maka Rahmanto menawarkan hal-hal yang harus dipertimbangkan dalam pemilihan bahan ajar sastra, melalui. Pertama, dari sudut bahasa. Kedua, dari segi kematangan jiwa (psikologi). Ketiga, dari sudut pandang kebudayaan para siswa. (Rahmanto,1998,p.25) Pemilihan sumber belajar untuk peserta didik harus disesuaikan dengan kematangan psikologis dan kebudayaan peserta didik. Hal itu agar proses pembelajaran selaras sehingga menimbulkan pemahaman yang mendalam dalam proses pembelajaran. Berdasarkan penjelasan di atas terlihat bahwa sastra bermanfaatsertamemilikinilaiyangmendalam dalam proses pembelajaran. Pemilihan bahan ajar menjadi sangat penting dilakukan. Salah satu karya sastra yang bermanfaat dan dapat digunakan sebagai bahan ajar dalam proses pembelajaran ialah novel Pulang karya Leila S. Chudori. Pulang merupakan karya sastra yang tidak hanya menghibur tetapi juga memberikan pendidikan yang menyoroti realitas sosial berupa masalah sosial dan berbagai peristiwa sejarah yang terjadi pada masyarakat Indonesia.

\section{METODE}

Penelitian ini menggunakan pendekatan penelitian kualitatif. Metode yang digunakan dalam penelitian ini adalah metode analisis isi yang didukung oleh teori strukturalisme genetik. Teori strukturalisme genetik adalah penelitian yang menuntun peneliti untuk menganalisis struktur pada karya sastra dan kemudian menghubungkan struktur yang ada di dalam karya dengan realitas sosial yang ada meliputi kondisi sosial pengarang, latar sejarah, budaya, dan sosial untuk menemukan pandangan dunia yang tercermin di dalam sebuah karya sastra.

Data dalam penelitian ini berupa kutipan-kutipan dalam novel Pulang I karya Leila S. Chudori Data tersebut didapat dari sumber data primer, yakni novel Pulang karangan Leila S. Chudori. Teknik pengumpulan data dalam penelitian ini berupa teknik dokumenter berupa kajian pustaka terhadap teks novel Pulang karya Leila 
S. Chudori yang dilakukan secara intensif. Studi dokumentasi yang dimaksudkan ialah dengan menggunakan analisis isi. Teknik pengumpulan data dalam penelitian ini dilakukan 1) Dokumentasi, yakni peneliti mengumpulkan, membaca, dan menguji sumber data. Pengujuan pertama: memahami dan menghayati secara kritis (utuh, menyeluruh) serta mempertajam, memperdalam pemahaman dan penghayatan untuk memilih dan menelaah data. Pembacaan dilakukan secara cermat dan mendalam sehingga penentuan bentukbentuk realitas sosial pada sumber data dapat dicapai. 2) Membaca ulang novel yang akan diteliti dengan cermat untuk mencari kata, kelompok kata, paragraf, dan wacana dengan menandai, mengutip, mencatat, bagianbagian yang dijadikan data dari sumber data.

Beberapa langkah yang dilakukan untuk menganalisis data antara lain, 1) menetapkan kriteria analisis, 2) Menganalisis unsur-unsur novel Pulang karya Leila S. Chudori 3) menganalisis unsur novel yang menggambarkan adanya bentuk-bentuk realitas sosial kemudian menghubungkannya dengan struktur sosial masyarakat 4) Menganalisis unsur novel yang menggambarkan adanya bentuk pandangan dunia pengarang kemudian menghubungkannya dengan biografi dan hasil wawancara terhadap pengarang 5) membuat interpretasi, 6) mengimplikasikan pola cerita tersebut dalam pembelajaran sastra di sekolah, 7) menarik kesimpulan. Prosedur analisis data yang digunakan ialah prosedur analisis isi Philip Mayring. Pemeriksaan keabsahan data yang digunakan dalam penelitian ini adalah ketekunan pengamatan, triangulasi dan pengecekan teman sejawat.

\section{HASIL DAN PEMBAHASAN}

Temuan penelitian ini diawali dengan mendeskripsikan struktur cerita yang dianalisis melalui analisis isi. Pertama, mengenai realitas sosial yang terdapat di dalam novel Pulang karya Leila S. Chudori.
Kedua, karena penelitian ini menggunakan kajian strukturalisme genetik, maka akan dikaji juga mengenai realitas yang terdapat di dalam tema, alur, tokoh dan penokohan, latar, dan sudut pandang. Selanjutnya unsur ekstinsik yang akan dikaji adalah struktur sosial masyarakat dan pandangan dunia pengarang. Untuk memahami pandangan dunia pengarang di dalam novel, maka akan dikemukakan juga riwayat hidup atau biografi pengarang dan proses kreatif pengarang dalam menulis Novel. Riwayat hidup dan proses kreatif Leila S. Chudori dalam menulis novel diperoleh dari berbagai sumber selain dari wawancara juga dari beberapa tulisan dari para pengamat sastra dan orang-orang yang pernah dekat dengan beliau. Riwayat dan proses kreatif penulisan novel Leila $S$. Chudori tersebut sangat membantu peneliti dalam mengkaji lebih mendalam tentang realitas sosial dalam novel Pulang.

Melalui riwayat hidup pengarang akan diketahui latar belakang pengarang sehingga dapat juga diketahui pandangan dunia pengarang dalam menciptakan sebuah karya sastra. Kehidupan sosial, budaya pengarang akan mempengaruhi penulisan karya sastra karena pengarang merupakan bagian dari kelompok sosial suatu masyarakat. Dengan demikian, pengarang dapat menggunakan pandangan dunia kelompok masyarakat. Dengan begitu dapat disimpulkan bahwa kehidupan sosial budaya pengarang akan menimbulkan pandangan dunia pengarang karena terbentuk dari pandangan pengarang setelah berinteraksi dengan pandangan kelompok sosial masyarakat.

$$
\text { Selanjutnya, agar dalam }
$$

mendeskripsikan dan mengkaji hasil temuan penelitian pada struktur novel, struktur sosial, dan pandangan dunia pengarang dapat dijelaskan dan dipahami dengan baik, maka berikut di bawah ini hasil penelitian mengenai novel Pulang karya Leila S. Chudori.

\section{1) Realitas yang terdapat dalam unsur novel Pulang kearya Leila S. Chudori}

Bentuk-bentuk realitas sosial yang 
terdapat di dalam novel terdapat dalam unsur pembangun novel seperti tema, tokoh/ penokohan, dan latar. Bentuk realitas tersebut didapatkan melalui pikiran, ide, gagasan, latar peristiwa di dalam cerita. Salah satu bentuk realitas yang terdapat dalam unsur novel melalui tema cerita. Tema secara umum dapat dipahami sebagai pokok pikiran yang dituangkan pengarang dalam sebuah cerita. Akan tetapi Nani Tuloli mengemukakan tema sebagai "Gagasan dasar umum yang menopang sebuah karya sastra yang terkandung di dalam teks sebagai sebuah struktur semantik dan yang menyangkut persamaan-persamaan maupun perbedaanperbedaan, tema disaring dari motif-motif konkrit yang menentukan urutan peristiwa atau situasi tertentu." (Tuloli, 2000, p.42) Berdasarkan pendapat di atas dapat dipahami bahwa tema merupakan gagasan umum yang menopang sebuah karya sastra sebagai sebuah makna. Tema dapat dilihat dari motif-motif konkrit yang ada di dalam sebuah cerita.

Sebagaimana halnya pendapat di atas, novel ini bertemakan "perjuangan" Tema perjuangan yang diusung di dalam novel ini dapat dilihat dari motif-motif perjuangan dan usaha para tokoh dalam cerita, seperti yang terdapat di dalam kutipan di bawah ini,

Aku berada di sini bukan karena melarikan diri dari bencana, tetapi karena sebuah garis hidup yang aneh dan tak terduga (aku sengaja belum menggunakan kata 'nasib') Dia tahu, aku tak peduli dengan marabahaya dan ingin segera kembali ke Jakarta atau Solo, meski itu berarti aku akan kena ciduk. (p.71)

Kutipan di atas menceritakan seorang tokoh utama yang yang terus berjuang agar dapat pulang ke Indonesia. Ia tidak dapat kembali ke Indonesia karena menghadiri sebuah konferensi seminar untuk wartawan. Meski begitu, dia menyadari bahwa perjuangannya untuk pulang ke tahah air jauh lebih besar dibanding kebencian dan teror yang datang kepadanya.

Selanjutnya, tema perjuangan dalam novel ini dapat dilihat dari motif lain, yaitu perjuangan yang dialami Lintang Utara untuk mengenal Indonesia. Lintang Utara. Ia adalah anak dari tokoh utama Dimas Suryo. Perjuangan yang dilakukan Lintang ialah perjuangan untuk mengenal Indonesia dan mencari jati dirinya. Sebagai anak yang terlahir dari dua orang tua yang berbeda kebangsaan dan besar di lingkungan keluarga yang hancur membuat Lintang Utara menjadi seorang wanita yang merasa tidak memiliki jati diri. Masa lalu ayahnya sebagai warga negara Indonesia yang "tidak tinggal" di Indonesia untuk alasan yang jelas membuatnya merasa jauh dan tidak mengenal Indonesia. Hingga nasib memilihnya untuk mengenal Indonesia secara langsung dengan datang sendiri ke Indonesia, untuk mengerjakan tugas kuliahnya. Dengan kedatangannya ke Indonesia itulah dia baru dapat memahami arti Indonesia baginya. Bahkan yang lebih penting dari itu, kedatangannya ke Indonesia memperat hubungannya dengan sang ayah karena Lintang akhirnya memahami betapa ayahnya memendam rasa rindu terhadap Indonesia tercinta. Di samping itu perjuangan Lintang Utara untuk mengenal Indonesia tidak tidaklah mudah, ia harus menerima cap sebagai anak tanahan politik, ia dibicarakan, dan bahkan ia sepmat mendapatkan visa untuk masuk ke Indonesia.

Berdasarkan kutipan di atas, maka secara umum tema di dalam novel ini ialah "Perjuangan" yaitu dapat dilihat dari beberapa motif yang mempengaruhinya sehingga menjadi tema besar perjuangan. Motif yang dimaksud ialah berupa perjuangan Dimas Suryo untuk tetap bertahan dan kembali ke Indonesia serta perjuangan generasi kedua yaitu Lintang Utara yang dicap sebagai anak ekstapol untuk mengenal jati dirinya dan tanah kelahirnannya. Maka berdasarkan motif tersebut, secara umum tema di dalam novel ini dapat dikatagorikan sebagai tema perjuangan. 
Tema perjuangan yang terdapat dalam cerita di atas sesuai dengan realitas sosial berdasarkan suber bahan bacaan dan dari hasil wawancara terhadap pengarang bahwa di luar negeri terdapat banyak ratusan bahkan ratusan bahkan ribuan warga Indonesia yang berjuang untuk kembali pulang ke tanah air. Mereka yang tidak dapat kembali ke tanah air kemudian mendapatkan predikat eksil politik.

Para eksil tidak dapat pulang ke Indonesia karena paspor mereka dicabut begitupuladenganstatuskewarganegaraannya pada saat itu. Namun, mereka tetap berjuang hingga nasionalisme mereka tumbuh karena kerinduannya terhadap Indonesia. Hal tersebut sesuai dengan ungkapan pengarang "Mereka yang tinggal jauh dari tanah air tapi masih merasa mereka adalah bagian dari Indonesia, tidak peduli apa jenis paspor yang dimiliki dan tidak peduli bagaimana pemerintah memperlakukan mereka."

Selain itu juga dalam sumber bacaan mengungkapkan bahwa terdapat jutaan eksil politik seperti Dimas Suryo yang menjelaskan bahwa Eksil politik yang nasibnya sama dengan Dimas Suryo hingga kini diperkirakan jumlahnya masih ribuan, bahkan mungkin lebih, dan tersebar di berbagai negara Eropa. Latar belakang yang membuat mereka terpaksa menjadi eksil politik sangat beragam. Tetapi secara umum alasannya ketika pada tahun 1950an. Presiden Sukarno mencanangkan Manipol USDEK (Manifestasi Politik UUD 1945, Sosialisme ala Indonesia, Demokrasi Terpimpin, Ekonomi Terpimpin dan Kepribadian Indonesia). Terkait dengan poin keempat, yakni Ekonomi Terpimpin, Sukarno menjabarkannya sebagai suatu citacita Indonesia sekian puluh tahun ke depan, yaitu Indonesia dengan ekonomi berdikari, yang sanggup mengolah segala bahan mentah, baik hasil tambang maupun pertanian dan perkebunan yang ada di Indonesia. Untuk itulah sejak 1960 hingga 1965 pemerintah secara bergelombang mengirimkam ribuan kaum muda untuk belajar di universitasuniversitas di negara-negara blok sosialis, misalnya Uni Soviet, Yugoslavia, Rumania, Cekoslovakia, Hungaria, Albania, Polandia, Bulgaria, Jerman Timur, Kuba, RRT, dsb. Negara-negara blok sosialis waktu itu memiliki kedekatan politik dengan Indonesia, dan hendak dijadikan sebagai model pembangunan industri oleh Presiden Sukarno). Mereka belajar di berbagai disiplin ilmu, dari teknik, kedokteran, ekonomi, pendidikan hingga linguistik. Mereka yang dikirim ke negara-negara blok sosialis itu belum tentu memiliki haluan politik dan ideologi pada PKI. Namun yang jelas mereka mendukung ide Nasakom-nya Sukarno.

Selanjutnya realitas yang terdapat pada tokoh cerita. Tokoh-tokoh yang ditampilkan oleh pangarang di dalam cerita terdapat beberapa tokoh dalam cerita yang kisahnya terisnpirasi dari beberapa realitas sosial yang terjadi di masyarakat hal tersebut sesuai dengan yang diungkapkan pengarang dalam wawancaranya bahwa ia telah melakukan perjalanan ke Paris pada tahun 1988. Pada saat itu ia belajar menganai para eksil politik Indonesia. Begitupun dengan kisah yang dialami Dimas Suryo dan kawankawannya. Sebagian kisah yang terdapat di dalam cerita berdasarkan keterangan penulis bahwa terinspirasi dari beberapa kisah nyata dalam realitas sosial yang terjadi di masyarakat. Hal tersebut sesuai dengan fakta yang ditemukan oleh pengarang bahwa di negara Eropa, Cina, dan Kuba banyak orang Indonesia yang nasibnya sama dengan Dimas Suryo yang berjuang dan memperjuangkan dirinya agar bisa kembali pulang ke Indonesia sebagai tanah airnya.

Selanjutnya ialah latar. Latar yang terdapat dalam Novel ini umumnya di Jakarta dan di Paris. Latar yang terdapat di dalam novel memperjelas realitas sosial yang terjadi di masyarakat. Latar dalam novel ini menceritakan keadaan Indonesia pada 1960. Keadaan sosial Indonesia pada novel Pulang karya Leila S. Chudori diceritakan Dimas 
Suryo seperti di dalam kutipan di bawah ini, ...Di tahun 1960-an, masa-masa sebelum Ayah meningalkan Jakarta, situasi politik sangat panas. Kau di kiri atau di kanan. Kau merah, merah jambu, atau hijau, dan kehijau-hijauan. Istilah dan terminologi bertaburan di dalam diskusi, bantahan, dan tuduhan serta jeritan:Manipol, Nekolim, Revolusi, Kontra-Revolusi, dan ratusan akronim buruk lainnya yang sama sekali ta menarik untuk diingat, apalagi untuk dipelajari dan diteliti. DI Zaman itu Indonesia tidak mengenal zona netral. Tak mengenal area kelabu. Kau harus bagian dari Kami atau Mereka...(p.234)

Kutipan di atas menggambarkan keadaan sosial Indonesia pada 196-an. Pada saat itu semua orang harus memilih kiri atau kanan. Seperti yang dialami Dimas Suryo yang memilih untuk tidak memilih dan hingga akhirnya dia dianggap karena telah memihak. Latar yang terdapat di dalam cerita ini sesuai dengan keadaan sosial masyrakat pada saat itu.

\section{2) Realitas sosial dalam novel Pulang ditinjau dari} Struktur Sosial Masyarakat.

Sesuai dengan pendapat K.J Vegeer yang menyatakan bahwa konsep realitas terbentuk oleh lingkungan yang memunculkan norma, kondisi sosial, dan tujuan sosial (Vegeer, 1990: 10) Hal tersebut didukung oleh pendapat Durkheim yang menggunakan istilah realitas sosial sebagai fakta sosial. (Berger, \& Luckmann, 1990: 28) Bentuk realitas sosial yang terdapat di dalam novel ini berupa fakta sejarah dan kondisi sosial yang terdapat di dalam kehidupan masyarakat. Realitas sosial di dalam novel sebagai karya fiksi sesuai dengan realitas pada kehidupan di dunia nyata. Bentukbentuk realitas yang terdapat dalam novel pulang meliputi 1) Tragedi 30 September 1965 2) Situasi Masyarakat Indonesia Setelah Tragedi 30 September 1965 3) Bergantinya Pemerintahan Orde Lama ke Orde Baru 4) Kondisi Sosial Eksil Politik Indonesia
5) Rezim Presiden Soeharto 6) Tragedi Trisakti Mei 1998 7) Etnis Tionghoa di Indonesia Mei 1998 8) Realitas sosial berupa masalah sosial dalam Novel 9) Realitas sosial berupa masalah sosial 10) Realitas sosial berupa kelas sosial dalam novel.

Peristiwa-peristiwa yang terdapat di dalam novel tersebut sangat relevan dengan realitas sosial yang terjadi pada masyarakat Indonesia. Hal tersebut sesuai dengan beberapasumberbacaanyangmengemukakan mengenai realitas yang terjadi di masyarakat Indonesia saat itu. Sejarah mencatat bahwa telah terjadi tragedi besar yang menimpa bangsa Indonesia yaitu meletusnya gerakan 30 September 1965. Pada saat itu jendraljendral diculik dan dibunuh oleh PKI. Hal tersebut juga diungkapkan oleh Manafe seperti yang terdapat di dalam kutipan, "Aksi penculikan dilakukan serentak yakni pada pukul 03.001 Oktober 1965. Pasukan yang menculik Jendral TNI AH Nasution pimpinan Pelda Djahurub menggunakan truk berangkat ke kediaman Pak Nasution." (Manafe, 90) Maka, berdasarkan penjelasan di atas bahwa cerita yang terjadi di dalam novel yang diceritakan oleh Dimas Suryo benar-benar terjadi di masyarakat Indonesia. Dengan begitu bahwa realitas yang terdapat di dalam novel sesuai dengan fakta yang terdapat di dalam sejarah Indonesia Sejarah mencatat bahwa adanya Instruksi Menteri Dalam Negeri No. 32/1981 dan pedoman pelaksanaannya yang menjadi dasar pencantuman kode-kode khusus dalam Kartu Tanda Penduduk ekstapol yang terkenal dengan singkatan ET. Instruksi Mendagri No 32/1981 tetang Pembinaan Pengawasan terhadap Bekas Tahanan dan Bekas Narapidana G30SPKI. Para tahanan dan bekas narapidana G30SPKI mendapatkan peraturan yang diskiminatif yang tertuju tidak hanya pada tanahan politik tetapi juga pada anak cucu mereka. Hal tersebut seperti yang diceritakan Leila S. Chudori melalui Lintang Utara yang mendapatkan perlakuan diskiminatif di lingkungan sosialnya. Selain 
mereka mempunya cap sebagai ekstapol atau ET. Mereka tidak mempunyai status kewaranegaraan yang jelas, eksil politik juga digambarakan sebagai berikut, seperti yang terdapat di dalam novel,

...Tentu saja bukan eksil politik jika tidak ada gangguan sehari-hari. Paspor dicabut, berpindah negara, berpindah kota, berubah pekerjaan, berubah keluarga...segalanya terjadi tanpa rencana. Semua terjadi sembari kami terengahengah berburu identitas seperti ruh yang mengejar-ngejar tubuhnya sendiri. Gangguan, atau Mas Nug lebih suka menyebutnya ,tantangan, yang kami hadapai datang bertubi-tubi. Karena itu, setelah keberhasilan malam pembukaan ini membutuhkan antagonis...(p. 120)

Kutipan diatas menjelaskan mengenai kondisi eskil politik yang dicabut paspornya, kemudian mereka berpindah Negara, berubah pekerjaan dan mereka mencari indentitas untuk mencari Negara yang dapat menerima mereka sebagai warganya. Hal tersebut sesuai dengan keadaan eksil politik di Indonesia yang sampai saat ini mereka dihukum tanpa melalui proses peradilan yang jelas. Selanjutnya, kondisi sosial yang terjadi pada eksil politik ialah disorganiasasi keluarga. Disorganisasi keluarga merupakan salah satu realitas sosial yang terjadi pada eksil politik. Hal tersebut terjadi terutama pada keluarga yang mengalami peristiwa tertentu seperti yang terjadi pada keluarga Dimas Suryo dan Hananto Prawiro yang memiliki latar dengan peristiwa 30 September.

\section{3) Realitas Sosial dalam Novel dikeaitkan dengan Pandangan Dunia Pengarang (World View)}

Hubungan antra struktur sastra dan struktur sosial dikaitkan dengan pandangan dunia pengarang. Sastra sebagai representasi dari pandangan dunia pengarang yang mawakilinya sebagai individu yang hidup di tengah-tengah masyarakat. Goldmann mengatakan bahwa pandangan dunia pengarang adalah sesuatu yang komprehensif dan menyeluruh yang berupa ide, gagasan dan perasaan yang menghubungkan secara bersama-sama antara individu dan anggota suatu kelompok sosial yang lain. (Goldmann, 1975) Pendapat tersebut mempunyai relevansi dengan temuan penelitian di dalam novel Pulang karya Leila S. Chudori.

Leila S. Chudori di dalam novel Pulang mengangkat tema mengenai peristiwa sejarah atau relaitas sosial yang terjadi pada masyarakat Indonesia. Ia menceritakan mengenai kehidupan eksil politik pada masa pemerintahan orde baru. Dalam temuan penelitian pada novel Pulang didapatkan sesuatu bahwa selaku wakil dari subjek kolektif pengarang memiliki pandangan dunia bahwa di dalam realitas sosial masyarakat Indonesa masih terdapat diskiminasi terhadap bebrapa eksil politik Indonesia. Seperti yang terdapat di dalam novel Pulang di bawah ini,

...Tetapi saya hanya ingin mncari sisi yang manusiawi karena ini sebuah film dokumnter. Saya hanya ingin menyorot nasib orang-orang akhibat kondlik politik yang kemudian berkahir dengan banjir darah, korban jiwa yang begitu banyak dan trauma politik yang begitu berkepanjangan serta indoktrinisasi yang luar biasa yag bisa melekat pada rakyat Indonesia... (p. 230)

Kutipan di atas, diwakili oleh Lintang Utara sebagai tokoh problematik di dalam cerita. Ia digambarkan sebagai generasi kedua setelah Dimas Suryo yang memiliki kompleksitas permasalahan di dalam hidupnya. Ia mencari jati diri dan identitas kebangsaannya serta selama perkembangan hidupnya ia dicap sebagai ekstahanan politik atas dosa yang tidak diketahuinya. Leila S. Chudori dalam wawancaranya ia menyatakan bahwa eskil politik merupakan warga negara Indonesia yang berhak mendapat kehidupan yang layak sebagaimana warga Indonesia pada umumnya. Sebagai seorang wartawan ia mengetahui dengan detail mengenail eksil politik di Indonesia. Sebagaimana novel yang ia tulis ini sebagian cerita yang ia tulis 
terinspirasi dari beberapa eksil politik yang telah ia wawancarai di Paris. Sebagai wartawan yang menentang betul paham komunis tetapi ia menentang diskirminasi terhadap eksil politik berhak mendapatkan perlindungan dan tempat yang layak di negaranya sendiri.

Selanjutnya, pandangan dunia pengarang yang didapat melalui tokoh yang menyatakan perlawanannya mengenai paham komunis. Pengarang, menyatakan melalui beberapa pikiran-pikiran, ide, gagasan yang dituangkah tokoh terutama tokoh utama seperti yang terdapat di dalam kutipan di bawah ini,

...Komunisme hanya satu kata yang manjur untuk dijadikan musuh bersama, kecuali jika mereka membaca diam-diam mahasiswa di Indonesia belum pernah membaca buku-buku Karl Mark atau tafsirnya karena ada larangan pemerintah, parnoia itu malah membuat anakanak muda tertarik mencarinya....dan seandainya mereka tahu, toh itu teori yang gagal di mana-mana. Tidak akan ada yang tertarik. Aku saja tidak, Bimo tidak. Dan bukan karena apa yang menimpa kami, justru karena kami membacanya sebagai mahasiswa dan menggunakan nalar...

(p. 369)

Kutipan di atas dilihat berdasarkan kacamata Sagara Alam sebagai pencerita. Ia menyatakan bahwa komunis merupakan suatu paham yang wajib dijadikan musuh bersama. Sebagai mahasiwa yang berpikir menggunakan nalar dan akal sehat Alam menentang betul paham komunis bukan karena paham tersebut telah menyengsarakan keluarga dan masa depannya tetapi karena ia benar-benar berpikir dan memahami teori. Berdasarkan pemahaman tokoh utama tersebut dapat disimpulkan bahwa pengarang memandang komunis sebagai salah satu paham yang harus dijauhi dan dimusuhi bersama. Hal tersebut seperti yang diungkapkan penulis dalam wawancaranya bahwa ia sangat menentang komunis yang sangat membahayakan bagi warga negara Indonesia.

\section{SIMPULAN}

Simpulan yang dapat ditarik dari penelitian yang berkenaan dengan realitas sosial dalam novel "Pulang" karya Leila S. Chudori di antaranya adalah (1) tema yang tedapat di dalam novel Pulang ialah perjuangan. Secara umum, tema perjuangan yang terdapat di dalam novel ini dipengaruhi oleh beberapa motif, di anataranya adalah perjuangan Dimas Suryo untuk dapat kembali mencium tanah air serta perjuangan Lintang Utara untuk mengenal tanah air Indonesia sebagai salah satu bagian dari hidupnya. Secara umum, latar tempat terjadinya peristiwa secara keseluruhan di dalam novel ini ialah di Jakarta dan di Paris. Sedangkan waktu terjadinya cerita ini dari tahun 1952-1998. Waktu dan tempat terjadinya peristiwa tersebut secara bersama-sama menggabarkan suasana yang saling menguatkan satu sama lain di tengah peristiwa yang terjadi. Secara umum peristiwa di dalam novel ini berlatarbelakang sejarah yaitu mulai dari masa-masa pembersihan segala sesuatu yang terlibat dengan PKI hingga berlatarkan orde baru dan diakhiri oleh peristiwa kerusuhan Mei 1996 yang berdampak pada kekerasan terhadap warga Tionghoa. Alur yang terdapat di dalam novel ini ialah alur campuran. Sudut pandang yang terdapat di dalam novel ini ialah campuran; (2) novel ini memiliki keterakitan yang sangat kuat dengan realitas yang terjadi di masyarakat. Realitas sosial yang diungkapakan oleh Leila S. Chudori berkaitan dengan peristiwa sejarah yang ada di Indonesia. Di antaranya ialah peristiwa yang terjadi di dalam novel sesuai dengan peristiwa yang ada di struktur masyarakat yaitu meliputi peristiwa 30 September 1965, situasi Indonesia setelah tragedi September 1956, surat perintah sebelas maret atau sering disebut Supersemar, eksil politik Indonesia, tragedi reformasi 1998, etnis Tionghoa di Indonesia serta kerusuhan Prancis 1965; (3) realitas sosial ditinjau dari pandangan dunia pengarang terlihat dari beberapa tokoh problematik yang terdapat di dalam 
novel, yaitu Dimas Suryo dan Lintang Utara. Melalui tokoh-tokoh peroblematik di dalam novel diketahui pandangan dunia pengarang yaitu di tengah sejarah Indonesia yang harus dipahami salah satunya ialah mengenal sejarah lain berupa nasib eksil politik di Indonesia. Pandangan dunia pengarang menunjukkan bahwa eksil politik yang dipandang sebelah mata oleh mayarakat dan pemerintah mereka butuh hidup normal sebagaimana manusia pada umumnya.

\section{DAFTAR RUJUKAN}

Berger, P. \& Luckman, T. (1971).The social contruction of reality; a treatise in the sociology of knowledge. London: Pengun Book.

Berger, P.L., \& Luckman, T. (1990).Tafsir sosial atas kenyataan. Jakarta: LP3ES.1990.

Chudori, Leila S. (2012). Pulang. Jakarta: Kepustakaan Populer Gramedia.

Dharma, B. (2012). "Sastra ideologi, pandangan dunia, korupsi, dan pelawanan. Jurnal Kritik Teori dan Kajian Sastra, No.2 (2),2012.
Djojosuroto, K. (2006). Analisis teks sastra dan pengajarannya. Yogjakarta: Penerbit Pustaka.

Emzir, \& Rohman, S. (2015). Teori dan pengajaran sastra. Jakarta: PT. Raja Grafindo.

Endraswara, S. (2002).Metodologi penelitian sastra. Yogyakarta: CAPS.

Goldmann, L. (1975). Towards a sociology of the novel. London: Cambridge University Press.

Rahmanto. (1988). Metode pengajaran sastra. Yogyakarta: Kanisus.

Ratna, N.K. (2005).Sastra dan cultural studies refresentasi fiksi dan fakta. Yogyakarta: Pustaka Pelajar.

Tuloli, N. (2000). Teori fiksi. Gorontalo: BMT Nurul Jannah.

Vegeer, K.J. (1990). Realitas sosial. Jakarta: PT.Gramedia Pustaka Utama.

Wellek, R., \& Warren,A. (1993). Teori kesusastraan. Jakarta: PT.Gramedia Pustaka Utama. 